Geistige Eigentumsrechte, was steht für die Entwicklungsländer auf dem spiel?

\title{
Intellectual Property Rights and the WTO: A Southern Perspective
}

D.M. Nachane

\section{CpenEdition}

\section{Journals}

Electronic version

URL: http://journals.openedition.org/sjep/679

DOI: $10.4000 /$ sjep.679

ISSN: 1663-9677

\section{Publisher}

Institut de hautes études internationales et du développement

\section{Printed version}

Date of publication: 1 April 1998

Number of pages: $25-46$

ISSN: $1660-5926$

\section{Electronic reference}

D.M. Nachane, «Intellectual Property Rights and the WTO: A Southern Perspective», Schweizerisches Jahrbuch für Entwicklungspolitik [Online], 17 | 1998, Online since 01 August 2012, connection on 07 September 2020. URL : http://journals.openedition.org/sjep/679 ; DOI : https://doi.org/10.4000/sjep. 679 


\title{
INTELLECTUAL PROPERTY RIGHTS AND THE WTO: A SOUTHERN PERSPECTIVE
}

\author{
D.M. NACHANE*
}

\section{INTRODUCTION}

\subsection{FORMS OF INTELLECTUAL PROPERTY RIGHTS (IPR)}

The concept of intellectual property is far from being a recent one. Even in the times of the Middle Ages, merchants were often granted exclusive rights to inventions via «letters of patent». In fact, the modern patent system may be traced directly back to a statute passed in Venice in 1474.

The most common forms of IPRs, currently in vogue, are the following:

口 patents;

๑ copyrights;

๖ trademarks;

๖ trade secrets and

口 plant breeders rights (PBRs).

Of the above instruments, patents and (to a lesser extent) PBRs have figured most prominently in the recent acrimonious TRIPs (Trade Related Intellectual Property Rights) debate. Our paper focuses almost exclusively on patents.

The organisation of the paper is as follows. The first section examines certain features of IPRs. Section 2 delves into the motivations behind the move to global strengthening of IPRs, initiated by the US and other developed countries. Section 3 shows the LDCs' perspective on IPRs. The legal aspects of the new IPR regime in the Indian context are explored in Section 4, whereas their likely economic impacts are discussed in Section 5. A post-mortem of the «opt-out» option is described in Section 6 with conclusions gathered in Section 7.

\subsection{PATENTS}

A patent is intended to protect a particular product or a process that is the outcome of inventive thought. It allows the patentee to forbid commercial exploitation of the product (or process) by others in the country of the patent issue, without an explicit licence from the patentee. However, in order to protect the diffusion of technological knowledge, two provisos are entered. First of all, the prohibition of exploitation (without a licence) is limited to a specific period. Secondly, if a patent is not used by its holder and a licence is not issued to another person, the patent holder can be compelled by law to issue a «compulsory licence» (or in extreme cases the patent can be even forfeited). The condi-

* Director, Department of Economics, University of Mumbai Vidyanagari, India. (Currently Hallsworth Fellow at the University of Manchester.) 
tions for granting a compulsory licence are regulated by the national patent act of the country in question.

Patent laws can thus vary among countries, in terms of three characteristics:

๖ life of the patent;

$\square$ conditions for granting compulsory licence or forfeiture;

$\square$ the scope of the product or process that can be patented ${ }^{1}$.

On the other hand, there is a considerable degree of unanimity, among national patent systems, on the following four criteria of eligibility for granting a patent:

utility;

- novelty;

๑ non-obviousness;

$\checkmark$ sufficient disclosure (in patent applications).

\section{STRENGTHENING GLOBAL IPRS}

\subsection{EMERGING TECHNOLOGY CHARACTERISTICS}

One of the primary reasons that the move towards a strictly global IPR regime is becoming more popular, in the developed world, is found in the fundamental changes of the character of technology, over the past two decades.

- Firstly, and perhaps most importantly, as highlighted by Mytalka (1987), Kaplinsky (1989) and Thurow (1997), the knowledge intensity of production has increased and so has the «science-content» of knowledge. As knowledge intensity has grown, the individual inventor has been increasingly replaced by the corporate entity. Simultaneously, the increasing "scientisation» has taken on considerable scope for scale economies (very often by transcending national boundaries). Thus the battle for IPR has become a high-stake war, involving mega corporations and transnational enterprises, rather than scattered individual scientists. This is particularly true of the pharmaceutical and biotechnology sectors.

- The «electronics revolution» has not only accelerated the pace of diffusion in the electronics sector, but has also made imitation costless and difficult to prove. This is particularly true in the field of semi-conductors, where duplication via reverse-engineering can be relatively easy. Thus, technological leakage is common and hence, invested interests in industrialised countries have been quite active in lobbying for stronger protection ${ }^{2}$.

a Perhaps the most striking technological development of the past few decades has been biotechnology, whose vast potential is yet to be realised, but which poses several problematical issues in the IPRs context. Firstly, until very recently, with the notable exception of the US, most national patent systems

1. The Indian Patents Act 1970, for example, recognises only process patents (i.e. not product patents) for food items, drugs, optical glass and semi-conductors. It also does not grant patents relating to certain items of atomic energy. The US Patents Laws, on the other hand, have virtually no exceptions on patentability, considering all «non-naturally occurring non-human multi-cellular living organisms including animals as patentable subject matter».

2. Largely as a result of such pressures, the US Copyright Law was amended in 1976 to extend copyright protection to computer programs, spreadsheets, films, music etc. and the US Semi-conductor Chip Protection Act of 1984 was introduced in order to grant a ten-year protection to inventions in the field of semi-conductor topography. 
have not provided patents for microorganisms. Considering that the peculiar feature of biotechnology is its considerable threshold of investment in resources, needed for identifying microorganisms, in the absence of adequate IPR protection, it is very likely that such an investment may fall short of the social optimum. Secondly, as opposed to other sciences, the link between the scientific origin of an idea in biotechnology and its commercial exploitation is direct, while the time lag between invention and innovation is virtually negligible. The «disclosure requirement» of the traditional patenting system may thus prove to be an inducement for illegal duplication in the absence of adequate safeguards.

The preceeding discussion highlights an important fact. Substantial technological changes have occurred in the past few decades that necessitate a revision of the traditional approach to IPRs in the industrialised countries of the West (especially the US). These countries alone can allocate the huge resources necessary for scientific enterprises. It is then no wonder that a large part of the initiative to strengthen IPRs globally has come from the West, with the US in the vanguard.

\subsection{US IMPERATIVES}

While technological characteristics are the motivating source for strengthening IPRs, their emergence on the Uruguay Round agenda owes a great deal to US initiatives. The US goals in the Uruguay Round may be formally described as:

๑ achieving a comprehensive and self-actuating Agreement on TRIPs to replace the mechanism of dispute resolution (in the area of IPRs) via ad-hoc country-specific approaches;

- legitimising the linkage between IPR issues and the global trading system by making trade sanctions a legitimate method of retaliation against erring nations.

There is no satisfactory analytical framework to explain US policy imperatives, although the UNCTAD (1990) report is an interesting attempt. The UNCTAD thesis is predicated on two major ingredients - the product cycle theory (Vernon, 1971) and the hegemonic-stability theory of international relations (Gilpin, 1987). As is well known, the products cycle theory postulates that major products are innovated by TNCs and produced initially in advanced countries. In the later stages of a product's life, the competitive advantage of location shifts to LDCs. A TNC (transnational corporation) may still retain control of these later stages of production, provided that the production technology has not passed into the hands of LDC firms. If the technology is transferred onto LDC producers, then they may well appropriate the major benefits of the later stages of the product cycle, at the expense of the TNCs. TNC lobbies would therefore be impelled to pressure their governments for stricter IPR regimes, both at home and abroad. However, applying pressure on foreign governments to be fined can only be the prerogative of a global hegemon.

The theory of hegemonic stability maintains that the global leadership and economic enforcement functions are usually devolved to the hegemon if one exists. Logically, markets will be relatively open in the presence of a hegemon and relatively protectionist in its absence. This hypothesis seems to be well 
illustrated by the experience of Britain in the 19th century and by the US in the early post-World War II phase. However, the hegemon that seeks to establish open markets for goods will also attempt to establish closed markets for intellectual property. Furthermore, concern with free trade of goods is likely to be paramount when the hegemon is in a strongly competitive position (or when most of its industries are in the early stage of the product cycle). On the other hand, IPRs become the dominant preoccupation when the hegemon looses its competitive edge, with the bulk of its industries in the advanced maturing stages of the product cycle. The UNCTAD report thus attributes the hardening of the US stance on IPRs, in the 1980s, to its declining competitive position (or what Bhagwati and Patrick [1990] call the "diminishing giant syndrome»). Interestingly enough, the theory also attempts to explain why trade retaliation emerges as the favoured instrument for seeking stricter IPR enforcement. The diminishing competitive edge of the hegemon means that foreign imports claim a large share in their own market, so that, in a sense, the economic weakness of the hegemon becomes precisely its political leverage.

The UNCTAD theory has several weaknesses but we shall not discuss them here, since they have already been discussed by the author in an earlier paper (Nachane 1995). However, the major contribution of the UNCTAD theory is that it highlights the critical fact that a nation's attitudes to IPRs evolve over time and that they are conditioned by its internal economic and political situation. More precisely, the statute of a national IPR regime will be the outcome of conflicting interests between innovators and imitators, as well as among other groups (especially consumers) in society, as resolved through the political process. As innovation proceeds apace, the interests of innovators dominate those of imitators so that a hegemon, in its early phases of domination, might even favour weak IPR regimes. ${ }^{3}$. Nonetheless, in the later stages, as imitators overshadow innovators, the same nation may become an advocate of a strong IPR regime.

\subsection{US POLICY INITIATIVES}

The discussion above should have made it reasonably clear that the US (and other developed countries) have a strong incentive to push for stricter intellectual property protection. US trade legislation, over recent years, increasingly reflects this preoccupation. Intellectual property rights were explicitly included in US trade legislation, for the first time, in Section 301 of the US Trade and Tariff Act of 1984, which represented a considerable hardening of the US's trade policy stance overall. The US omnibus Trade and Competitiveness Act of 1988 (especially Sections 301, 310) took trade retaliation even further. The authority of trade retaliation, previously vested in the President, was shifted to the USTR (United States Trade Representative). A Super 301 provision enjoined on the USTR the responsibility for identifying and compiling inventories of «unfair» practices in foreign countries. From these inventories, the USTR was supposed to select «priority countries and practices», set deadlines for expurgating these practices and impose trade restrictions on countries that

3. We may cite the US non-participation in international copyright arrangements for the first 100 years of the systems existence as a case in point. 
refuse to be fined. Furthermore, a new special 301 provision was introduced for identifying countries with weak IPR regimes ${ }^{4}$.

Unilateralism however has its limitations, the chief among them being the following:

a maintaining up-to-date inventories of «malpractices» has its costs and effective action is inevitably slow ${ }^{5}$;

- retaliation threats are ineffective against countries with limited presence in US markets;

- trade embargoes entail a great deal of surveillance;

- unilateralism tarnishes the US political image in the targeted countries.

However, all of the above problems would be avoided if a multilateral body (like the then existing GATT) could be persuaded to put IPRs on its agenda. This was precisely the strategy adopted by the US (and the developed world) as soon as the Uruguay Round was initiated in 1986. The conclusions of the Round have been an exemplary victory from the US viewpoint, especially on IPRs. The TRIPs Agreement of the WTO, comprising 73 Articles, covers all forms of IPRs including copyrights, neighbouring rights (i.e. rights of performers, broadcasters and phonogram producers), integrated circuits, designs and patents. The agreement (see Hoekman and Kostecki 1995) seeks to:

- establish minimum levels of protection for most forms of IPRs;

- prescribe redressal procedures in TRIPs-based conflicts;

a strive for enforcement of IPR standards in members countries;

- extend basic GATT principles of national treatment, transparency and MFN (most favoured nation) clause, to IPRs.

Many countries of the Third World have insisted that US unilateralism is now superfluous, because of the new TRIPs Agreement, and that Section 301 should be expunged. Unilateralism is, however, far from being dormant, although the US government has promised to persuade the Congress to take a new look at Special 301 and Super 301. If past experience with the GATT is any indication, the stalemate is likely to continue indefinitely into the future - only the severity of the «arm twisting» may be somewhat abated ${ }^{6}$.

\section{THE LDC VIEWPOINT}

\subsection{PARADIGMS OF TECHNICAL CHANGE IN LDCS: 1. DEPENDENCY THEORY}

To appreciate the attitude of LDCs on IPRs, it is vital to study their perceptions of the role of technological progress in economic development, prevalent in these countries. The dominant paradigm in this regard, in the early 1970s, was the so-called «dependency school» that originated in Latin America, with heavy

4. Bhagwati and Patrick (1990) have dubbed these measures as «aggressive unilateralism» both because the US unilaterally determines what constitutes «unfairness» in the trade practices of other countries and because the other countries are expected to undertake unilateral liberalisation.

5. Bayard and Elliot (1992) found that out of a total of 82 cases initiated over 1975-1992, only 41 resulted in some form of retaliation

6. In a case involving automative spring assemblies in 1981, wherein Canada had challenged Section 337 of the US Trade Act, it was ruled by the GATT that this Section was compatible with Article XX (d) of GATT (Hudec [1993] presents several such cases). 
overtones of the Marxist theory of imperialism (Furtado 1964; Warren 1980; Fransman 1985). The dependency school posits that there is a secular tendency for LDCs to veer towards technological dependence on industrialised countries, due to a combination of factors, namely:

口 the income distribution in LDCs is overwhelmingly skewed in favour of the upper classes, which dominate the market for consumer goods;

- the operation of the «demonstration effect» moulds the taste of the elite classes in LDCs to the kind of consumer goods that prevail in the advanced countries;

- the local manufacture of goods for elitist consumption is usually accomplished through technology imports (in the form of inputs, machinery and know-how) from the industrialised countries;

- the necessary foreign exchange resources for such imports are generated by primary product exports.

Several corollaries follow from these basic tenets of the dependency school:

- TNCs become the dominant suppliers of technology to LDCs;

- technology terms supply creates conditions favourable to the emergence of monopolies in LDCs;

ป such monopolies exhibit no technological dynamism of their own;

$\checkmark$ technical innovation in developed countries is of the labour-saving, capitalising variety, that is antithetical to the factor endowment situation in LDCs (Stewart 1972);

- IPRs are a powerful medium for perpetuating the technological monopoly of the TNCs and, by implication, the technological dependence of the LDCs on the developed world (Vaitsos 1972).

The last proposition is particularly relevant to the theme of our paper and underlies the strong opposition to the stiffer IPR regime among the LDCs, expressed in a series of initiatives at the UN, beginning with the Brazilian resolution in 1961 and followed by similar resolutions at Nairobi (1981) and Geneva (1982, 1984). It is also worth noting that several developed country economists have also questioned the relevance of a strong IPR regime for LDCs? .

The early 1970s were a halcyon period for the dependency theory. It held full sway over intellectual opinion in LDCs. Several cataclysmic developments of the last decade have, however, put the theory to severe strain. The collapse of the erstwhile Soviet Union and the Communist regimes in Eastern Europe was widely heralded as symbolising «the end of history» (Fukuyama 1992) and the unchallenged triumph of Western liberalism. This resurgence of neo-liberalist thought had a profound impact on development theory. Other developments reinforced the tide against dependency-oriented thinking. On the one hand, suprastatal agencies, like the IMF and the World Bank, were trying to encourage structural adjustment in the debt-ridden countries of the South, based on «the logic of the market place». On the other hand, LDCs were increasingly fascinated with the examples of the Asian Tigers and the «flying geese» formation,

7. Thus, both Penrose (1951) and Greer (1973) have suggested that LDCs should be exempt from international patent agreements. More recently, Bifani (1990) has also taken a fairly sympathetic view of the IDC position, in the context of the Uruguay Round negotiations, he remarks that «it is somewhat ironical that liberalisation of international trade will be now pursued through the growing global monopolisation of one of the most important factors of production, that is knowledge, a process facilitated by the absence of internationally agreed antitrust rules». 
led by Japan (Chew and Denemark 1996). Dependency theory was rapidly losing adherents among the intellectuals and policy-markers in LDCs. Time and again, scholars of this tradition have tried to point out that the success of the Asian Tigers was attributable more to the state's strategic role in these economies than to the unfettered working of the market. Moreover, the failures of «really existing socialism» in the East were nowhere equal to the failure of «really existing capitalism» in the South (Frank 1996). These arguments failed to make an impression for the simple reason that the failures of socialism were far more obvious, and one may add, spectacular than those of capitalism.

\subsection{PARADIGMS OF TECHNICAL CHANGE IN LDCS: 2. NEO-SCHUMPETERIAN THEORY}

Already by the mid-1970s, a new paradigm of development was on its way. Stewart (1977) provided a seminal contribution to the new thinking by talking about the advantages of being a «late-comer» in the development process. She attributed the success of several Asian countries, including the Tigers, to their concentration on incremental technical progress rather than their focus on major technology breakthroughs; or, in her words, they embarked on «technology following» strategies rather than «catching up» strategies. The new theory that emerged may be appropriately termed neo-Schumpeterian since, like the original Schumpeter (1934) model, it focuses on technological change; however, there is a fundamental difference: whereas Schumpeter was concerned with path-breaking technological successes, the new theory focused on marginal (i.e. incremental) technological change. The neo-Schumpeterian theory (Freeman et al. 1982; Katz 1984; Teitel 1984; Fransman 1985; etc.) focuses on the advantages accruing to «technology followers», that is: reduced costs of knowledge acquisition and risk bearing. Imitation is particularly attractive to LDCs since it can be based on relatively shallow levels of knowledge and has very little chance of failure, in contrast to pioneering research that may require in-depth knowledge, based on huge R\&D investment, and where risks of failure are high.

The implications of the neo-Schumpeterian view for IPRs have not been examined hitherto but they seem to be relatively straightforward. LDCs (like India, Sri Lanka and Brazil) that possess threshold scientific and technological capabilities can successfully resort to a «technology following» strategy and an IPR system, conducive to such a strategy. An IPR system of the desired kind would thus recognise «minor» or «utility» patents, i.e. one where the «non-obviousness» requirement, referred to in Section 1 , would be considerably diluted. If «utility» patents were admitted in national IPR systems of LDCs, domestic innovators of such products could easily withstand potential foreign competition in this area. The grant of patents to foreigners for major technical changes will then be a matter of secondary importance to domestic innovators, who will occupy themselves with «inventing around the patent». It is important to note that the TRIPs Section of the WTO does not preclude «utility» patents. LDCs, in modifying their patent laws, would be well advised to bear in mind the potential advantages of such patents.

The two major paradigms of technical change that we have reviewed have led to a vertical schism among LDC intellectuals. The dependency theory still appeals to the majority, who sees the WTO as yet another form of neo-imperialism. 
There is also a more pragmatic minority of intellectuals and policymakers who view the WTO as a challenge, rather than as a threat, that is largely under the influence of neo-Schumpeterian thinking.

\section{TRIPS - LEGAL AND CONSTITUTIONAL IMPLICATIONS FOR INDIA}

Even prior to the coming into existence of the WTO, a certain amount of international cooperation in IPRs was already occurring, in order to obtain a minimal degree of harmony among country specific IPRs ${ }^{8}$. The main problem, however, with the several existing conventions, was their lack of authority in ensuring member-compliance and the absence of effective dispute-settlement mechanisms. The major attractions of the WTO, for proponents of strengthened IPRs are twofold - firstly, its recognition of trade retaliation as a legitimate sanction against non-compliance and secondly, its implementation of an effective dispute settlement machinery.

If one closely follows the extended discussions that occurred in the LDCs, in the wake of the conclusion of the Uruguay Round, in academic as well as popular fora, one is likely to get the impression that the issues are innumerable as well as extremely complex. Additionally, it is the TRIPs Agreement that seems to be the major bone of contention.

We have attempted here to group the various issues under three major headings and, more precisely, to discuss them in the Indian context ${ }^{9}$. Thus, we address ourselves to the following three issues:

a Does the TRIPs Agreement require fundamental departures from the existing intellectual property protection system in India?

- Is the TRIPs Agreement an infringement to Indian national sovereignty?

- And finally, what are the likely long-term economic consequences, for India, of this agreement?

The first two issues are taken up for consideration in this section and the third issue forms the subject matter of the following section.

\subsection{TRIPS AND THE INDIAN PATENTS ACT (1970)}

The national legislation currently in force, in India, regarding patents, is the Indian Patents Act (1970). The TRIPs Agreement is based on the Paris Convention and includes three major additional features: the scope of patentability, the terms of the patent, and the «burden of proof» provision (for process patents).

8. The major conventions were (i) Paris Convention (1883, revised 1967) mainly concerning patents, trade marks and industrial designs and administered by the WIPO (World Intellectual Property Organisation); (ii) Berne Convention (1886, revised 1971) dealing with copyrights and also administered by the WIPO; (iii) Universal Copyright Convention (1952) administered by UNESCO; (iv) UPOV (1961, revised 1972, 1978 and 1991) also administered by WIPO and dealing with protection of IPRs in plant varieties; (v) IPIC (1989) covering integrated circuits under WIPO; (vi) Geneva Convention (1971) dealing with phonograms and administered jointly by ILO, UNESCO and WIPO; (vii) Rome Convention (1961) pertaining to «neighbouring rights» (performers, broadcasters, etc.) jointly administered by the ILO, UNESCO and WIPO.

9. Far for me to claim that the Indian case is representative of most LDCs. However, many of the fears that have been expressed in the Indian context would, I believe, apply to several LDCs with differing emphasis. 
Taking all features of the TRIPs Agreement and the Indian Patents Act (1970) into account, we may identify the following nine areas of potential conflict:

๑ national treatment;

$\checkmark$ priority rights;

$\checkmark$ independence of patents;

- importation;

๑ compulsory licensing;

๑ patent forfeiture;

口 scope of patents;

$\checkmark$ terms of protection;

a burden of proof.

We will, in turn, discuss each of these aspects.

\section{$\square$ National treatment}

Article 2 of the Paris Convention enjoins on signatory parties the obligation to provide nationals of other members the same protection of IPRs as awarded to their own nationals, as well as similar safeguards against infringements of their rights. Sections 133 and 134 of the Indian Patents Act (1970) explicitly recognise the national treatment principle (Ponnuswami 1987).

\section{$\square$ Rights of Priority}

Article 4 of the Paris Convention accords rights of priority in the matter of patent application to any national of a member of the Convention. This priority is valid for a period of 12 months, from the date the first patent application was filed in any member country. Section 135 of the Indian Patents Act accords similar rights.

\section{$\square$ Independence of Patents}

Article 4 bis of the Paris Convention stipulates that patents, requested in the various countries of the Union by nationals of member countries, shall be deemed independent of patents obtained for the same invention in other countries (whether or not they are members of the Convention). As pointed out by Sangal (1987), the independence of patents is not listed specifically in the Indian Patents Act but, at the same time, no provision of this Act contradicts this presumption.

\section{$\square$ Importation of Articles}

Article 5 of the Paris Convention explicitly states that «importation by the patentee into the country where the patent has been granted of articles, manufactured in any of the countries of the Union shall not entail forfeiture of the patent». In other words, imports are accepted as a legitimate means of working the patent. This issue is a very controversial one and has often been invoked in the past by those opposed to India's adherence to the Paris Convention. Section 83 of the Indian Patents Act articulates the general consideration that patents are granted for being worked in India, whereas Section 90(d) maintains that «reasonable requirements of the public», with respect to the patent, are not satisfied «if the demand for the patented article in India is being met to a substantial 
extent by importation from abroad». It is important to note that importation per $s e$ is permitted under the Indian Patents Act and does not, in itself, constitute grounds for revocation of the patent. It is only when a substantial part of the demand is being met by importation that compulsory licensing or patent forfeiture is called into action. Therefore, the Indian Patents Act is not totally incompatible with the provision of the Paris Convention.

\section{$\square$ Compulsory Licensing}

The Paris Convention stipulates that a compulsory licence may not be applied for before a period of four years has expired from the date of filing the patent application, or before a period of three years has elapsed from the date of granting the patent, whichever period expires later. Such a compulsory licence shall be non-exclusive and non-transferable and can be refused if the patentee provides legitimate reasons for non-use or insufficient use. The difference with the Indian Patents Act, in this respect, is a minor one - the Act specifies that the period for which a compulsory licence cannot be issued is three years from the date of sealing the patent.

\section{$\square$ Patent Forfeiture}

The Paris Convention does not address the problem of forfeiture, except in cases where the alleged misuses of the patent cannot be remedied by compulsory licences. Proceedings for forfeiture cannot be instituted prior to the expiry of at least two years from the grant of the first compulsory licence. In the Indian context, the issue of forfeiture raises some legal issues of interpretation. Section 89 of the Indian Patents Act, that deals with patent revocation for non-use, is completely in agreement with the provisions of the Paris Convention. However, Sections 64-66 of the Indian Patents Act make no reference to compulsory licensing as a precondition for forfeiture and may thus be found at variance with this provision of the Paris Convention.

Thus, as far as the Paris Convention's provisions of the TRIPs are concerned, the differences with the Indian Patents Act are not significant and can be remedied without too much difficulty. However, wide discrepancies are evident when we consider the additional TRIPs provisions.

\section{$\square$ Scope of Patents}

The TRIPs Agreement has made the scope of patents virtually universal. The Indian Patents Act, by contrast, has several exceptions to patentability. Section 4 of the Act excludes inventions related to certain aspects of atomic energy from the scope of patents and Section 5 grants process patents only (no product patents) in the case of inventions in the fields of medicine, food articles, drugs, optical glass, certain alloys, etc.

\section{$\square$ Terms of Protection}

The TRIPs Agreement lays down a minimum term of twenty years (from the filing date) for the patent's terms. On the contrary, the terms granted under Section 53 of the Indian Patents Act are considerably shorter. More specifically, the term of a process patent in the areas of food, medicines or drugs is either seven years from the filing date of a patent application or five years from the date of 
granting, whichever is shorter. For all other inventions, a uniform term of fourteen years from the date of the patent filing is stipulated.

\section{$\square$ Burden of Proof}

As for the infringement of process patents, the TRIPs Agreement (Article 34) claims that «the judicial authorities shall have the authority to order the defendant to prove that the process to obtain an identical product is different from the patented process». This has been widely construed by Indian analysts as being contrary to the spirit of the Indian legal system, which holds a person innocent until proven guilty. There are at least three qualifications to this interpretation. Firstly, the principle of «innocent until proven otherwise» was mainly applicable to criminal procedures, whereas here we are talking of civil infringements. Secondly, the TRIPs Agreement also states that the burden of proof is on the alleged infringer only if at least one of the following conditions holds: «(i) the product obtained by the patented process is new and (ii) there is a substantial likelihood that the identical product was made by the process and the owner of the patent has been unable through reasonable efforts to determine the process actually used.» Finally, the legitimate interests of the defendant in protecting his business have to be taken into consideration - article 34, (2) and (3).

Therefore, the major difficulties in modifying the Indian Patents Act stem from the additional provisions (apart from the Paris Convention) introduced into the TRIPs Agreement.

\subsection{OTHER FORMS OFIPRS}

Let us now briefly turn to other major forms of intellectual property and their position in India.

Regarding copyrights, the TRIPs Agreement relies heavily on the Berne Convention. As India is already a signatory to the Berne Convention, no major adjustment was necessary for copyright legislation in India to conform to the TRIPs norms. Nevertheless, the Indian Copyright Act was amended in 1994 to incorporate the following features:

a Even though the TRIPs Agreement does not insist on Article 6 bis of the Berne Convention, Section 57 of the Indian Copyright Act, after modification in 1994, allowed for substantial incorporation of this Article's provisions. These provisions confer on the author, independently of his economic rights, the right to claim authorship of his work and to object to any distortions or mutations of the same. These rights pass on to the author's legal representatives after his death.

a In accordance with Article 10 of the TRIPs Agreement, copyright protection was extended in 1994 to computer programs as well as to source codes.

- The term of copyright (Section 22 of the Indian Copyright Act) extends to 60 years after the author's death; this greatly exceeds the 50 years protection recommended by TRIPs.

$\checkmark$ The rights of broadcasting organisations and performers were considerably enhanced after the 1994 amendments (Sections 37 and 38). 
The case of trademarks and designs presents very few problems. The TRIPs Agreement seldom conflicts with the Indian Trade and Merchandise Marks Act of 1958. There was one minor point of disagreement on service brands. They could not be registered under Indian law, but the Trade Mark Bill (1993) enabled such brands to be registered by conforming to the TRIPs provision. Similarly, the term of protection for industrial designs, granted under the Indian Designs Act (1911), is five years whereas the corresponding TRIPs requirement is ten years, but this is a minor modification that can be taken care of without too much difficulty.

For a comprehensive discussion of other forms of IPRs, one can refer to Debroy (1996).

\subsection{WTO AND THE INDIAN CONSTITUTION}

India's ratification of the WTO treaty was viewed by several commentators as being a «sell-out» and contradicting the provisions of the Indian Constitution. The arguments used by the proponents of this viewpoint were twofold. First of all, they argued that the Union Cabinet itself did not have the authority to sign the Treaty without the approval of the Parliament. Some even called for a referendum, citing the examples of EU countries in the matter of the Maastricht Treaty. Secondly, since several aspects of the WTO dealt with subjects in the "States' List», the consent of at least a majority of the twenty-two states of the Indian Federation was a prerequisite to ratifying the Treaty. A noted environmentalist, Dr Vandana Shiva, appealed to the Delhi High Court, demanding that the Government of India restrain from signing the WTO Treaty, notably Article 27.3(b) of the TRIPs Agreement. The Delhi High Court, however, rejected the restraining injunction.

Entry 14 of list 1 of the Seventh Schedule makes it quite clear that the Indian Constitution empowers the executive to ratify and sign international treaties and conventions, provided that neither restriction nor infringement of rights would result from such an act. In the event of any such restriction or infringement, the Parliament must sanction any necessary legislation. The Delhi High Court judgement, mentioned above, may be interpreted as a precedent, supporting the view that no basic rights had been infringed, when the Government of India signed the WTO Treaty. This also lays to rest all of the controversy surrounding this issue (see Debroy [1996] for more details).

\section{TRIPS AGREEMENT - ECONOMIC CONSEQUENCES}

In discussions on the likely economic consequences of the new TRIPs regime on LDCs, two opposing views may be discerned. On the one hand, the traditional, dependency theory-inspired view postulates that strong IPRs will have deleterious consequences on LDCs. On the other hand, there is the nascent belief (a possibly influential view) that such an empowerment is an absolutely necessary precondition for LDCs to become integrated into the global economy and develop sustainably high economic growth. The quality of the debate has suffered from inadequate availability of sector-specific data. However, the 
debate has brought to light certain key issues, while pointing out what institutional changes would be necessary to mitigate the damages of a strong IPR regime in some sectors, or to maximise its benefits in others.

\subsection{TRADITIONAL VIEWPOINT ON TECHNOLOGY TRANSFER}

The basic theoretical argument for strong IPR protection is extremely simple. If returning to innovative activity (which is, in essence, a public good) can be better appropriated, it would encourage innovation and hence productivity and economic growth. This argument has sometimes been further simplified by identifying patents as IPRs major safeguards, and by linking enhanced patent protection to improved manufacturing productivity and economic growth.

The available empirical evidence in developed countries does not support the causal chains in the above analysis. The important surveys of US industries, undertaken by Mansfield et al. (1977) and Levin et al. (1987), rank patents fairly low, among various instruments, as a method of appropriating returns on intellectual property (except in the case of pharmaceuticals). Similarly, Watanabe's (1985) study of Japanese firms ranks patent protection below inter-firm competition, as an inducement to innovative activity. Historical studies of the Netherlands and Switzerland (such as those of Schiff [1971]), during their patent-free years, show no evidence that their economic prospects were being hampered by their weak IPR protection systems. Thus, in general, the link between IPRs and innovative activity, in industrialised countries, is tenuous (further details on this point may be found in Siebeck et al. (1990).

Similar surveys on LDCs are not available; however, even if they were, it would be difficult to envisage that the above conclusions would be reversed. As a matter of fact, the link between domestic IPRs and domestic innovative activity, in a LDC, is much less direct that in an industrialised country; this can be explained by the fact that LDCs nationals hold a very small proportion of the total number of patents (the figure is in the range of 8-10\% for India) drawn in that country. It was precisely this consideration that prompted Penrose (1951) to state: «These countries (LDCs) receive nothing for the price they pay for use of foreign inventions or for the monopoly they grant to foreign patentees.»

However, an indirect link could still exist between strong IPR regimes in LDCs and their economic growth if: (i) such IPR regimes lead to greater innovative activity abroad and (ii) the fruits of such innovative activity result in more rapid or cheaper transfer of technology from industrialised countries to LDCs. There is some evidence to support the first of these contentions in Lipsey et al. (1990). They claim that US firms that invest in production operations in LDCs are more R\&D intensive than similar US firms that invest in developed countries. The second contention (about the transfer of technology) is far more controversial. In one of the first systematic expositions on this question, Vaitsos (1972) took an extremely pessimistic view: he regarded patents as a means of blocking, rather than promoting, technology transfers, because, in his view: «Patents give an exclusive monopoly position in a national market and by not being exploited, they function so as to block the transfer of technology related to the patented products... the closer a patent is to a final product the more it tends directly and 
indirectly to block transfer of non-patented technology, since that product can be imported from abroad in secure monopoly-controlled markets.»

Restrictive business practices, that foreign patent holders have undertaken in LDC markets, have also been documented. The more important of these are:

口 price fixing (i.e. prices charged by the licensee are fixed or controlled by the patentee);

- discriminatory rates (discriminatory royalty rates charged to different licensees);

- tie-in-arrangements (longer royalty rates, linked to purchases of other products from the licensor);

- limitations on the resale of patented products in domestic or world markets.

It is interesting to note that one of the avowed negotiating objectives of the LDCs in the Uruguay Round was to link the establishment of stronger IPR regimes with an easier transfer of technology, from the industrialised to the developing world. However, such a link is conspicuously absent in the final WTO Agreement.

\subsection{THE ALTERNATIVE VIEWPOINT ON TECHNOLOGY TRANSFER}

The theoretical case for stronger IPRs in LDCs comes from Mansfield (1988), Primo Braga (1989) and Sherwood (1989, 1990). Mansfield, for example, points out that «a reasonable amount of respect for IPRs» constitutes a threshold mass for initiating technological development in LDCs. Similarly, Sherwood (1990) draws attention to the role of IPRs in fostering «an inventive habit of mind in the population, in encouraging industry-university interactions and in the diffusion of corporate business practices». Frischtak (1989) delineates the mechanism by which a sound IPR regime induces firms to make stronger commitments to R\&D activities. Dollar (1986) and Guin Ru (1988) show that foreign investment inflows are positively correlated with the strength of IPR protection in the host country. On the other hand, Marjit (1994) demonstrates that global R\&D investments may gravitate towards LDCs, as the latter strengthen their patent regimes.

Empirical evidence to support some of the above contentions is not lacking. Ozawa (1985) cites the example of Japan, where a relatively strong IPR system increased the flow of technology and investment from the West. The World Development Report (1991) documents the successful technology transfer that has taken place in Singapore, South Korea, Taiwan and Hong Kong. China is another striking example, where strengthening IPR protection and restructuring laws regarding foreign investment has resulted in sustained capital inflows over the past two decades (Paulwitz 1993).

In the Indian context, beneficial perceptions of a strong IPR system are most evident in the works of Desai $(1985,1988)$ and others such as Pillai (1979), Katrak (1985), Deolalikar and Evenson (1990) and Subrahmanian (1993). Desai's (1988) conclusions, based on data from Indian firms in the mid-1980s, should be repeated here. He came to the conclusion that multinationals are not the dominant technology suppliers of India and that technology imports did not lead to the creation of monopolies. Nevertheless, he is inclined to place the 
blame for India's poor technology visibility on the Government's active protection of industrial inefficiency. Katrak's (1985) and Subrahmanian's (1993) studies, though operating on different time spans and data sets, find similar conclusions, indicating strong complementarity between technology imports and domestic R\&D. Deolalikar and Evenson (1990) succeed in establishing a positive correlation between grants of patents in US and inventive activity in India. This may also be viewed as supporting the complementarity hypothesis.

However, this viewpoint has two basic limitations. The theoretical underpinnings have not been sufficiently clarified. Moreover, whatever relations have been made explicit are strongly grounded in neo-classical methodology, that may have severe limitations when applied to LDCs, especially in the dynamic context of technological change (Nelson and Winter 1982; Fransman 1985). From the empirical standpoint, many of the causal relationships identified would involve fairly long time-spans (e.g. the regression between R\&D expenditures and technology imports, studied by Subrahmanian [1993]). This would call for data that extend over a long period of time, which may rarely be available.

\subsection{THE PROCESS OF TECHNOLOGY TRANSFER IN INDIA - ADDITIONAL CONSIDERATIONS}

\section{$\square$ Pre-Reform Situation}

The traditional view of technology transfer, outlined in Section 5A, was highly relevant to the Indian situation of the 1960s. The picture, however, has changed considerably since the 1970 s. It must be conceded that, from a long-term perspective, India's technology import policy has displayed a degree of flexibility that has had a significantly beneficial effect on the country's industrial technological capacity (Bell and Scott-Kemmis 1985). Certain additional features of the actual technology transfer process also deserve some attention (the discussion pertains to the pre-reform period).

- The common perception that Indian buyers of technology prefer to import cheap, low-cost technology is far from the truth. Indian firms, on the contrary, prefer to import the most advanced and up-to-date technology and whatever technology transfer has occurred has been at the buyers' initiative rather than at the initiative of the suppliers (Alam 1985).

- An important aim of Indian technology policy, in the pre-reform period, was to discourage imports of packaged technology and turn-key plants. As a result, most of the technology had to be imported in an unpackaged form.

a One of the many import constraints on the transfer of technology has been the ceilings on royalty and know-how payments (usually 5\% of technology imports). These ceilings are well below the royalty rates that prevail elsewhere (UNIDO 1977).

- Altogether, the three factors above have meant that Indian firms have gone in for smaller technology packages. While the technology may often be of recent vintage, the range of products and processes encompassed by the collaboration are considerably less than what the supplier is willing to offer (Alam 1985). 
- Another point worth highlighting is the duration of collaboration. An upper limit of five years, for such collaboration, was in force from the early $1960 \mathrm{~s}$ to the late 1980s. The motivations behind the ceiling were to control the foreign exchange outflow, while simultaneously accelerating the efforts of Indian firms to absorb imported technology. The actual results have been the obverse of those expected. The Indian firms' access to technology has been severely curtailed (because of the suppliers' reluctance to transfer technology, involving short streams of royalty flows, and because of the Indian firms' own inability to absorb complex technologies in a relatively short span of time).

The problem with Indian $R \& D$ expenditure is not, as is usually imagined, its low level of $0.8 \%$ of the GDP (for the year 1995); it is higher than most middle income developing countries (excepting Korea). But its composition and lack of focus and direction are the main problems. Much of the R\&D in the public sector is earmarked for customer services and expenditure on bureaucrats' travel, entertainment, etc. Besides, where government ministries are involved, funding of projects is often based on patronage rather than on genuine merit ${ }^{10}$.

\section{$\square$ Post-Reform Scenario}

As an integral part of its liberalisation drive, the Indian government issued, in August 1991, a New Industrial Policy Statement, which modified several existing provisions. In 35 high-priority industries, it became possible for foreign equity participation, up to $51 \%$ of total equity, to receive automatic approval. Foreign technical agreements, involving lump sum payments of up to $\$ 0.3$ million (RS 1 crore), royalties of $5 \%$ on domestic sales or $8 \%$ on exports, and up to ten years duration, could also receive such approval. Hiring foreign technicians and foreign testing of indigenous developed technologies was also freely permitted. Repatriation of dividends was permitted, on the condition that dividend outflow was balanced with export earnings, over a seven-year period.

One of the major issues of interest in this paper is how the new TRIPs regime will affect the development prospects of LDCs like India. The survey, by Siebeck et al. (1990), is quite exhaustive in this regard and we will therefore confine ourselves to only two issues that have not been raised in this survey.

Firstly, the TRIPs regime, with its strengthened intellectual property protection, will almost certainly increase the willingness of technology suppliers to transfer new technology to LDCs, due to a reduced fear of illegal imitation. It would be generally agreed that a part of the lump sum payment, demanded by technology suppliers, is a kind of risk premium against technological leakage. With a strong IPR regime in place, the risk premium will go down and the increased competition among technology suppliers will also, in all likelihood, diminish royalties. Thus, it is quite likely that with a strong IPR regime, LDCs will have greater access to technology, at a cheaper rate. In the case of India, the loosening of constraints on technology imports, alluded to above, will strongly reinforce this tendency, as well as make new technology more readily available. 
The second issue we will discuss is that of the controversy over product vs process patents. Developed countries have long been arguing in favour of product patents, especially in the food, chemicals and pharmaceutical sectors (where alternative processes can be used to produce the same product, the patenting of each one of these processes being cumbersome and difficult). LDCs, on the contrary, maintain that product patents discourage R\&D efforts, since new processes can only be protected through dependent patents, conditional upon authorisation of the principal patent (Bifani 1990). Furthermore, product patents stimulate imports rather than domestic production of the concerned product ${ }^{11}$. Industrialised countries express the fear that process patenting alone can lead to widespread counterfeiting. LDCs, on the other hand, are concerned that product patents, in the fields of food, fertilisers, pesticides, pharmaceuticals, etc., might raise prices in these sectors which are of vital importance to their developmental needs and can have adverse welfare effects on large sections of the vulnerable population.

The TRIPs Agreement has given precedence to the advanced countries' viewpoint. Product patenting has been made universally applicable and the period of protection has been extended substantially. This has raised a host of issues for LDCs, especially in the areas of pharmaceuticals and agriculture. However, as these are being discussed in separate articles, in this volume, we will not dwell upon them here.

\section{THE «OPT-OUT» OPTION - A POST MORTEM}

At the time when the Dunkel Draft was being actively debated in India, one persistent strand of action, advocated by several commentators, was some form of «opt-out» option. In its extreme version, a total withdrawal from the GATT was envisaged, whereas in its moderate versions, the strategy advocated was to sign only selected provisions of any new agreements that would emerge (though whether such a selective approach to international treaties was feasible, is doubtful, to say the least) ${ }^{12}$.

The signing of the WTO has laid to rest the controversy in India, but a postmortem is still desirable. It is very likely that some «opt-out» version will be brought up by LDC politicians and intellectuals, time and again, at the slightest ruffling of sensibilities on global issues. Since India's withdrawal from the WTO is extremely unlikely, we will concentrate on the more moderate version of the «opt-out» strategy, in which certain provisions of the WTO are violated, either by deliberate design or negligence (ignoring, for the time being, the feasibility of such a course of action from the point of view of international law).

11. Mansfield et al. (1977) have noted that process patents are a more effective vehicle of technology transfer than are product patents; the argument was further elaborated by Bifani (1990). Several other arguments have also been invoked in the product vs process debate (Kabiraj 1994).

12. Speaking in the name of the extreme version, note Nanjundaswamy's following statement (8 May 1993, Mainstream): «I have been saying that just like what Russia did for a few decades - developing inside an iron curtain and the way China developed behind a bamboo curtain, I would like India to encircle itself with a khadi curtain.» Shukla ( 24 July 1993, Mainstream) adopts a more moderate position: «The fear of isolation is conveniently used by those who are willing to make significant concessions to the other side but are afraid of the political fallout at home. The protagonists of avoiding isolation at any cost rationalise their belief in terms of the absolute superiority of multilateralism to other modes of international relations in trade and economic masters. But neither the history nor the practice of multilateralism in GATT supports this belief.» 
Of course, the consequences of reneging on a particular provision of the WTO can never be assessed, even approximately, since the nature of the trade retaliation that will inevitably follow has not been spelled out anywhere in the WTO Agreement. It will, among other things, depend on which charter of the agreement has been abrogated. Suppose, for the sake of specificity, that India is found to have reneged on its TRIPs commitments when these come up for review around the year $2000^{13}$. The US, in all probability, would invoke the Special 301 provision. One would expect that the minimum level of retaliation could be the suspension of preferential treatment, on certain Indian export items, under the Generalised Scheme of Preferences (GSP). The EU members would also, in all likelihood, execute a similar threat. About $15 \%$ of India's exports to the US and about 18\% of its exports to the EU currently qualify for GSP treatment. It is doubtful that India could retain the existing markets for such exports, in case their GSP status would be revoked. The issue, however, deserves more careful examination. If the GSP status of imports from a number of LDCs were revoked simultaneously, the damage to individual LDCs would be considerably less. Thus, the extent of the loss to a specific country via suspension of GSP would depend on whether the country stood alone in its defiance or whether the action was being taken by several countries in unison. But trade retaliation could go much further, depending on the extent to which the country in question was violating an international charter. In the case of extreme violations, total trade embargo for limited periods cannot be ruled out.

There is also a more moderate and constructive approach to the issue of global trade dominance by developed countries. This approach encourages LDCs to form regional trading arrangements, among themselves, with a view to consolidating their countervailing power in world trade agreements. This strategy has considerable emotive appeal, representing in a way the economic counterpart of the «non-alignment movement».

In spite of its many attractions, however, the economic basis of the South-South trade strategy is rather weak. The traditional model for explaining trade flows between countries has been the Heckscher-Ohlin theory ${ }^{14}$, that assigns to each country a comparative advantage in the commodities using that country's abundant factor intensively. Empirical evidence seems to be in consonance with the predictions of this theory, for North-South trade or, in general, for countries at dissimilar levels of development (Tharakan 1984). It is, however, a weak explanation for trade between countries at comparable levels of development (whether of the North or the South).

Trade between countries with similar levels of development is much better explained by Linder's (1961) hypothesis of intra-industry trade. This hypothesis attributes the observed findings on trade expansion consequent to the narrowing of income differences between the countries to the phenomenon of «demand overlap»; it increases bilateral trade in specific varieties of similar goods. However, this possibility emerges only when incomes have risen substantially and consumer tastes have acquired a high degree of sophistication. It is thus erro-

13. This is a very real possibility in view of the fact that at least two attempts to obtain a modified version of the Indian Patents Act (1970) passed in the Parliament have been unsuccessful.

14. As Havrylyshyn (1985) has shown, the Heckscher-Ohlin theory is also successful in explaining trade between LDCs which are at different levels of economic development. 
neous to suppose that intra-industry trade could form the basis for South-South trading arrangements. Currently, South-South trade accounts for about 7 to $8 \%$ of global trade ${ }^{15}$, though this proportion will certainly increase as incomes rise in the South. Thus, whereas in the long run, South-South trade could offer some prospects, in the short and medium runs, the South will have to be heavily trade-dependent on the North.

Thus, neither the «clause by clause» approach to WTO ratification nor a significant re-orientation of South-South trade are economically viable options for LDCs. Their self-interest dictates participation in multilateral organisations, however unfair these may become.

Some Indian commentators never tire of citing China's impressive economic performance in spite of being outside the GATT as conclusive evidence that isolationism works. However, these glib defenders of the «iron» and the «bamboo» curtains forget the basic fact that even the severest autocratic regimes find it difficult to stop domestic consumers from being attracted to foreign goods. Furthermore, several items of mass domestic consumption (e.g. textiles) rely on imported machinery for their manufacture. Some isolationists even point to the gains that can accrue through illegal imitation and counterfeiting, overlooking the fact that even such activities need a minimum of technical expertise, which may not be forthcoming in the total absence of global trade. But the argument is really going too far when one considers that China has been trying to gain admittance to the $\mathrm{WTO}^{16}$. A country would hardly be knocking at the WTO doors, if it were fully convinced of the benefits of remaining outdoors. We have hitherto considered only the trade-related aspects of the isolationist strategy, but if one also takes into account the fall out on foreign investment and aid, then an «opt-out» strategy could be seen as nothing short of economic «harakiri».

\section{CONCLUSIONS}

This paper has ranged over a wide spectrum of issues relating to IPRs in the context of LDCs (with special reference to India). The roots of the polarisation between North and South views may be traced back to the fundamental nature of the technological change that has occurred in the past few decades. It may also be linked to greater US intransigence on trade issues (since the 1980s), due to its diminished hegemonic position in global trade. The Indian case also illustrates the difficulties that many LDCs will face in transforming their weak IPR regimes, in order to conform to the stiffer regime dictated by the WTO. In spite of having adhered to the WTO, India has been able neither to modify the Indian Patents Act (1970) nor to install an effective sui generis system for protecting plant varieties.

Thus, LDCs will typically find themselves powerless when enacting the necessary legislation, in the face of opposition from social activists and environmentalists on the one hand, and sections of jingoistic political opinion on the other. The WTO, of course, will be far from sympathetic to the demonstrated impo-

15. Computed by the author from the IMF Directory of Trade Statistics (various issues).

16. This issue figured prominently at the Sino-US summit held in October 1997. 
tency of LDC governments in the matter of national legislation ${ }^{17}$. Thus, most LDC governments are going to find themselves on the horns of a rather unpleasant dilemma.

When examining the economic consequences of the TRIPs Agreement, we have focused on the Indian case. However, the conclusions can be easily applied to the wider LDC context. Thus, the economic consequences will depend primarily, not only on the precise IPR regime that will emerge, but also on several related factors, such as the official stance on foreign collaborations and investment, and on issues such as subsidies and local concessions for R\&D in firms, universities, etc. A question that has rarely been asked, but which is a critical one in my opinion, is whether now that the developed countries have succeeded in having an IPR regime of their choice, sanctified by the WTO, they will comply with the long-standing reciprocal LDC demand to make the transfer of technology more flexible and easy. No explicit provision to this effect is to be found in the WTO Agreement.

The final part of our paper showed that backing out of the WTO, entirely or partially, was hardly a worthwhile option for LDCs. The WTO is a Hobson's choice for the Third World.

The character of the WTO as it has emerged probably reflects several phenomena: the emergence of the US as a political hegemon (in view of the eclipse of the erstwhile USSR), precisely at the time when its economic hegemony is under challenge; the rise of trading blocs world-wide and the breakdown of LDC solidarity. In the era of international Darwinism, ushered in by the WTO, the sauve qui peut philosophy is going to increasingly pervade the trade policy of LDCs. There is the very real danger that the «scramble for markets», ushered in by this process, will aggravate regional conflicts in the Third World. This presents additional grounds for apprehension among LDCs.

17. In December 1996, the WTO Dispute Settlement Panel found India to have failed its obligations under Articles 70.8 and 70.9 of TRIPs. It noted that «we do not agree with India that the transitional arrangements of the TRIPs Agreement necessarily relieve India of the obligation to make legislative changes in its patent regime during the first five years of operation of the agreement». 


\section{REFERENCES}

Alam, G. (1985): «India's Technology Policy and its Influence on Technology Imports and Technology Development». Economic and Political Weekly, Special Number, vol. 20, pp. 2073-2080.

Anderfelt, U. (1971): International Patent Legislation and Developing Countries, Marginus Nijhoff, The Hague.

Barton, J.H. (1991), «Patenting Life», Scientific American, vol. 264(3), pp. 40-46.

Bayard, T.O. and K.A. Elliot (1992), «Aggressive Unilateralism and Section 301: Market Opening or Market Closing», World Economy (November issue), pp. 685-706.

Belcher, B. and G. Hawlin (1994), «A Patent on Life: Ownership of Plant and Animal Research» in K.R.G. Nair and A. Kumar (ed.), Intellectual Property Rights, Allied Publishers, New Delhi.

Bell, M. and D. Scott-Kemmis (1985): «Technology Import Policy: Have the Problems Changed?, Economic and Political Weekly, special number, vol. 20, pp. 1975-1990.

Bhagwati, J. and H. Patrick (ed) (1990): Aggressive Unilateralism: America's 301 Trade Policy and the World Trading System, University of Michigan Press, Ann Arbor.

Bhargava, P.M. (1995): «Biotechnology's Decade of Stagnation», Economic and Political Weekly, vol. 30(48), pp. 3049-3050.

Bifani (1990): «The New Mercantilism and the International Appropriation of Technology» in Technology, Trade Policy and the Uruguay Round, U.N., New York.

Brady, N. (1982): «Chemistry and World Food Supplies», Science, vol. 218, pp. 847-853.

Brim, C. (1987): «Plant Breeding and Biotechnology in United States of America: Changing Needs for the Protection of Plant Varieties» in Proceedings of the Symposium on the Protection of Biotechnological Inventions, Ithaca, New York.

Brown, W.L. (1988): «Plant Genetic Resources: A View from the Seed Industry» in J.R. Kloppenburg (ed.), Seeds and Sovereignty, Duke University Press, Durham, N.C.

Buttel, F.H., M. Kenney and J. Kloppenburg (1985): «From Green Revolution to Biorevolution: Some Observations on the Changing Technological Bases of Economic Transformation in the Third World», Economic Development and Cultural Change, vol. 34(1), pp. 31-56.

Chew, S.C. and R.A. Denemark (ed.) (1996): The Underdevelopment of Development: Essays in honour of Andre Gunder Frank, Sage Publications, London.

Debroy, B. (1996): Beyond the Uruguay Round: The Indian Perspective on GATT, Response Books, New Delhi.

Deolalikar, A.B. and R.E. Evenson (1990): «Private Inventive Activity in Indian Manufacturing: Its Extent and Determinants» in R. E. Evenson and G. Ranis (ed.), Science and Technology: Lessons for Development Policy, Westview, Boulder, Colorado.

Desai, A.V. (1985): «Indigenous and Foreign Determinants of Technological Change in Indian Industry», Economic and Political Weekly, vol. 20, pp. 2081-2094.

- (1988): «Technology Acquisition and Application: Interpretations of the Indian Experience» in R.E.B. Lucas and G.F. Papanek (ed.), The Indian Economy: Recent Developments and Future Prospects, Oxford University Press.

Dollar, D. (1986): «Technological Innovation, Capital Mobility and the Product Cycle in North-South Trade», American Economic Review, vol. 76, pp. 177-190.

Frank, A.G. (1996): «The Underdevelopment of Development», in S.C. Chew and R.A. Denemark (ed.), The Underdevelopment of Development: Essays in honour of Andre Gunder Frank, Sage Publications, London.

Fransman, M. (1985): «Conceptualising Technological Change in the Third World in the 1980s: An Interpretive Survey», Journal of Development Studies, vol. 21(4). pp. 575-652.

Freeman, C., J. Clark and L. Soete (1982): Unemployment and Technical Innovation: A Study of Long Waves and Economic Development, Frances Pinter, London.

Frischtak, C.R. (1989): The Protection of Intellectual Property Rights and Industrial Technology Development in Brazil, The World Bank, Washington.

Fukuyama, F. (1992): The End of History and the Last Man, Free Press, New York.

Furtado, C. (1964): Development and Underdevelopment, University of California Press.

Gilpin, R. (1987): The Political Economy of International Relations, Princeton University Press.

Greer, D.F. (1973): «The Case against the Patent System in Less-developed Countries», Journal of International Law and Economics, vol. 8(2).

Guin, Ru, Q. (1988): «A View from a Commercial Official of the People's Republic of China» in C.E. Walker and M.A. Bloomfield (ed.), Intellectual Property Rights and Capital Formation in the Next Decade, American University Press, Washington.

Havrylyshyn, O. (1985): «The Direction of Developing Country Trade: Empirical Evidence of Differences between South-South and South-North Trade», Journal of Development Economics, vol. 19(3).

Hoekman, B. and M. Kostecki (1995): The Political Economy of the World Trading System: From GATT to WTO, Oxford University Press, Oxford.

Hudec, R. (1993): Enforcing International Trade Law: The Evolution of the Modern GATT Legal System, Butterworth, New York

Hughes, J. (1988): «The Philosophy of Intellectual Property», Georgetown Law Journal, vol. 77(2), pp. 287-366.

Kabiraj, T. (1994): «Intellectual Property Rights, TRIPs and Technology Transfer», Economic and Political Weekly, vol. 29(47), pp. 2990-2998.

Kaplinksy, R. (1989): «Industrial and Intellectual Property Rights in the Uruguay Round and Beyond», Journal of Development Studies, vol. 25(3), pp. 373-400.

Katrak, H. (1985): «Imported Technology, Enterprise Size and R\&D in a Newly Industrialised Country: The Indian Experience», Oxford Bulletin of Economics and Statistics, vol. 47(3). 
Katz, J. (1984): «Domestic Technological Innovations and Dynamic Comparative Advantages: Further Reflections of a Comparative Case Study Program», Journal of Development Economics, vol. 16 (No 1/2), pp. 13-37.

Kurth, J. (1979): «Political Consequences of the Product Cycle: Industrial History and Policy Outcomes», International Organisation, vol. 33(1), pp. 1-34

Levin, R.C., A.K. Klevorick, R.R. Nelson and S.G. Winter (1987): «Appropriating the Returns from Industrial R\&D», Brookings Papers on Economic Activity, vol. 3, pp. 783-820.

Linder (1961): An Essay on Trade and Transformation, John Wiley, New York.

Lipsey, R.E., M. Bolmstrom and L.B. Kravis (1990): «R\&D by Multinational Firms and Host Country Exports» in R.E. Evenson and G. Ranis (ed.), Science and Technology: Lessons for Development Policy.

Mansfield, E. (1988): «Intellectual Property Rights, Technological Change and Economic Growth» in C.E. Walker and M.A. Bloomfield (ed.), Intellectual Property Rights and Capital Formation in the Next Decade, United Press of America, Lanham.

Mansfield E., J. Rappoport and others (1977): «Social and Private Rates of Return from Industrial Innovations», Quarterly Journal of Economics, vol. 91(2), pp. 221-240.

Marjit, S. (1994): «Trade Related Intellectual Property Rights and GATT: A Theoretical Evaluation», Economic and Political Weekly, vol. 29(53), pp. 3327-3332.

Mytalka, L.K. (1987): «Knowledge-intensive Production and the Changing International Strategies of Multinational Firms» in J.A. Caporaso, A Changing International Division of Labour, Lynne Reiner Publishing, Co., Boulder.

Nachane, D.M. (1995): «Intellectual Property Rights in the Uruguay Round - An Indian Perspective», Economic and Political Weekly, vol. 30(5), 4 Feb. 1995, pp. 257-268.

Olson, M. (1965): The Logic of Collective Action: Public Goods and the Theory of Groups, Harvard University Press, Cambridge, Mass.

Ozawa, T. (1985): «Macroeconomic Factors Affecting Japan's Technology Inflows and Outflows: The Post-War experience» in N. Rosenberg and C. Frischtak (ed.), International Technology Transfer, Praeger, New York.

Paulwitz, E. (1993): The Patent System - An Instrument of the Technological Policy of Developing Countries, Friedrich Ebert Stiftung, New Delhi.

Penrose, E. (1951): The Economics of the International Patent System, John Hopkins University Press, Baltimore.

Pillai, P.M. (1979): «Technology Transfer, Adaptation and Assimilation», Economic and Political Weekly, vol. 14 (November).

Piore, M.J. and C.F. Sabel (1984): The Second Industrial Divide: Possibilities for Prosperity, Basic Books, New York.

Ponnuswami, K. (1987): «Accession to the Paris Convention for Protection of Industrial Property - A Plea for Fresh Thinking» in P.S. Sangal and K. Singh (ed.), Indian Patent System and Paris Convention: Legal Perspectives, Wadhwa \& Co., Allahabad.

Primo, Braga, C.A. (1989): «The Economics of Intellectual Property Rights and the GATT: A View from the South», Vanderbilt Journal of Transnational Law, vol. 22(2), pp. 243-264.

Sangal, P.S. (1987): «Paris Convention and the Indian Patent System: Legal Perspectives» in P.S. Sangal and K. Singh (ed.), Indian Patent System and Paris Convention: Legal Perspectives, Wadhwa \& Co., Allahabad.

Schiff, E. (1971): Industrialization without National Patents, Princeton University Press.

Schumpeter, J.A. (1934): The Theory of Economic Development, Harvard University Press, Cambridge, Mass.

Sherwood, R.M. (1989): «New Theory of Conductivity in Licensing», Les Nouvelles, vol. 24(4), pp. 186-189. (1990): Intellectual Property and Economic Development, Westview Press, Boulder.

Siebeck, W.E. (ed.) (1990): Strengthening Production of Intellectual Property in Developing Countries: A Survey of the Literature, World Bank D.P. 112, Washington D.C.

Stewart, F. (1972): «Choice of Technique in Developing Countries», Journal of Development Studies, vol. 99-191. (1977): Technology and Underdevelopment, Macmillan, London.

Subrahmanian, K.K. (1993): «Technological Capability Under Economic Liberalism: Experience of the Indian Industry in the 80s» in Y.K. Alagh, R.J. Mody and R.D. Desai (ed.), Sectoral Growth and Change, Har-Anand Publishers, New Delhi.

Teitel, S. (1984): «Technology Creation in Semi-industrial Economies», Journal of Development Economics, vol. 6, pp. 39-61.

Tharakan, P.K.M. (1984): «Intra-industry Trade between the Industrial Countries and the Developing World», European Economic Review, vol. 26, pp. 213-227.

Thurow, L.C. (1997): “'Needed: A New System of Intellectual Property Rights», Harvard Business Review (Sept.-Oct. issue), pp. 95-103.

UNIDO (1977): National Approaches to the Acquisition of Technology, Development and Transfer of Technology Series Number 1 .

UNCTAD (1990): Uruguay Round: Further Papers on Selected Issues, New York.

Vaitsos, C. (1972): «Patents Revisited: Their Function in Developing Countries», Journal of Development Studies, vol. 9(1), pp. 71-98.

Vernon, R. (1971): Sovereignty at Bay: The Multinational Spread of US Enterprises, Basic Books, New York.

Warren, B. (1980): Imperialism: Pioneer of Capitalism, New Left Books, London.

Watanabe, S. (1985): «The Patent System and Indigenous Technology Development in the Third World» in J. James and S. Watanabe (ed.), Technology, Institutions and Government Policies, Macmillan, London. 